\title{
More than one species of Messor harvester ants (Hymenoptera: Formicidae) in Central Europe
}

\author{
Birgit C. SCHLICK-STEINER ${ }^{1,2 *,}$, Florian M. STEINER ${ }^{1,2 *}$, HeINo KONRAD ${ }^{1}$, BÁLINT MARKÓ $^{3}$, SÁndOR CSŐSZ $^{4}$, \\ GERHARd HELLER ${ }^{5}$, BeATrix FERENCZ ${ }^{6}$, Botond SIPOS $^{6}$, ERHARd CHRISTIAN ${ }^{2}$ and Christian STAUFFER ${ }^{1}$ \\ ${ }^{1}$ Institute of Forest Entomology, Forest Pathology and Forest Protection, Department of Forest and Soil Sciences; ${ }^{2}$ Institute of \\ Zoology, Department of Integrative Biology, Boku, University of Natural Resources and Applied Life Sciences Vienna, \\ Hasenauerstr.33, A-1190 Vienna, Austria; e-mails: h9304696@edv1.boku.ac.at; christian.stauffer@boku.ac.at. \\ ${ }^{3}$ Department of Taxonomy and Ecology, Babes-Bolyai University, str. Clinicilor 5-7, 400006 Cluj-Napoca, Romania \\ ${ }^{4}$ Hungarian Natural History Museum, Baross u. 13, 1088 Budapest, Hungary \\ ${ }^{5}$ Stauferring 47, D-55218 Ingelheim, Germany \\ ${ }^{6}$ Department of Experimental Biology, Babes-Bolyai University, str. Clinicilor 5-7, 400006 Cluj-Napoca, Romania
}

Key words. Formicidae, Messor, harvester ants, cryptic species, biodiversity, mitochondrial DNA, molecular taxonomy, phylogeny, systematics

\begin{abstract}
It is commonly held that Central Europe harbours but a single harvester ant species, namely Messor structor. Recently discovered bionomic differences between two Central European populations, which may reflect interspecific variation, cast doubt on this assumption. In the present study we test alternative hypotheses - one versus two harvester ant species in Central Europe and adjacent regions - by investigating the genetic diversity of ants determined as M. structor or close to it ("M. cf. structor"). Sequences of the mitochondrial COI gene revealed two major lineages of different but partially overlapping geographic distributions, both occurring in Central Europe. The existence of a cryptic species within $M$. cf. structor is the most plausible interpretation, since the sequence divergence between the two major lineages equals those between M. capitatus, M. concolor and M. bouvieri. The phylogenetic analyses revealed a distinct substructuring for both of the detected major lineages and the possible existence of additional cryptic species.
\end{abstract}

\section{INTRODUCTION}

The myrmicine harvester ant genus Messor is mainly distributed in the Palearctic region (Bolton, 1982; Agosti \& Collingwood, 1987; Cagniant \& Espadaler, 1997). Bolton (1995) lists 105 recognized species worldwide. At the beginning of the last century there were a series of taxonomic revisions (Santschi, 1917, 1923, 1927; Kuznetzov-Ugamsky, 1927; Finzi, 1929). Since then modern taxonomists have conducted only partial revisions, which are confined to particular geographic regions or to certain species groups (e.g., Arnol'di, 1977; Bolton, 1982). The present taxonomic situation is thus unsatisfactory. For Central Europe (Austria, Czech Republic, Germany, Hungary, Poland, Slovak Republic and Switzerland) the occurrence of a single Messor species has been accepted (e.g., Stitz, 1939; Kutter, 1977; Seifert, 1996), and most of the current faunas (Gallé et al., 1998; Seifert, 2001; Czechowski et al., 2002; Steiner et al., 2003; Neumeyer \& Seifert, 2005) contain only one species, Messor structor (Latreille, 1798). Bezdečka (1996) and Werner \& Bezdečka (2001) list Messor muticus (Nylander, 1849), which is currently regarded as a junior synonym of M. structor (Atanassov \& Dlussky, 1992; Table 1), and Markó \& Csősz (2002) record M. muticus, in addition to $M$. structor, for Hungary. Based on current data, M. structor, which was originally described from
Brive-la-Gaillarde, France, occurs in North Africa and the Middle East, Southern, Central and Eastern Europe, Asia Minor, the Caucasus and Central Asia (Fig. 1; Czechowski et al., 2002). The only revision of the $M$. structor species group (Bernard, 1955) is rather cursory and does not mention origin and deposition of the investigated material.

The lengthy list of junior synonyms of M. structor (Table 1), combined with the lack of a proper revision of these taxa, and the occasional acceptance of different synonyms as valid species (Bernard, 1967; Bezdečka, 1996; Werner \& Bezdečka, 2001; Markó \& Csősz, 2002) raise serious questions about the biological identity and status of $M$. structor. In addition, a recent investigation of the life history of Messor cf. structor (Schlick-Steiner et al., 2005b) revealed a tendency for colony organisation and behaviour among Central European harvester ants to differ. These authors found that populations in Lower Austria did not swarm and were unicolonial (sensu Wilson, 1971 and Crozier \& Pamilo, 1996: ants from different nests intermingle due to the absence of clear colony boundaries). German Messor ants, in contrast, are reported to display swarming flight and multicoloniality, i.e., strict separation of single colonies (Heller, 1971; Seifert, 1996; Fig. 1). Such differences in life history may reflect intraspecific variation or the existence of distinct

\footnotetext{
* These authors contributed equally to the work.
} 
TABLE 1. List of taxon names currently regarded as junior synonyms or subspecies of Messor structor (Latreille, 1798).

\begin{tabular}{|c|c|c|c|}
\hline Original combination & Author & Type locality & Current status / Comments \\
\hline Formica structor & Latreille, 1798: 46 & France & combination in Messor: Emery $(1897: 238)$ \\
\hline Formica rufitarsis & Fabricius, 1804: 406 & Austria & junior synonym of structor: Nylander (1856: 85) \\
\hline Formica lapidum & Fabricius, 1804: 407 & Austria & junior synonym of structor: Nylander (1856: 85) \\
\hline Formica aedificator & Schilling, 1839: 56 & Poland & junior synonym of structor: Mayr (1855: 464) \\
\hline Myrmica mutica & Nylander, 1849: 39 & Russia & junior synonym of structor: Mayr (1855: 464) \\
\hline $\begin{array}{l}\text { Stenamma (Messor) structor } \\
\text { var. tyrrhena }\end{array}$ & Emery, 1898: 141 & Italy & $\begin{array}{l}\text { combination in Messor: Emery (1908: 456); junior synonym of } \\
\text { structor: Emery (1921: 210) }\end{array}$ \\
\hline Messor structor var. clivorum & Ruzsky, 1905: 735 & Turkestan & junior synonym of structor: Dlussky et al. (1990: 224) \\
\hline Messor tataricus & Ruzsky, 1905: 738 & Turkestan & $\begin{array}{l}\text { subspecies of clivorum Arnol'di (1977: 1644); junior synonym } \\
\text { of structor: Dlussky et al. (1990: 224) }\end{array}$ \\
\hline Messor platyceras & Crawley, 1920: 163 & Persia & subspecies of structor: Bolton (1995: 256) \\
\hline Messor platyceras var. rubella & Crawley, 1920: 164 & Persia & junior synonym of clivorum: Emery (1921: 210) \\
\hline $\begin{array}{l}\text { Messor barbarus subsp. } \\
\text { varrialei }\end{array}$ & Emery, 1921: 215 & Turkey & junior synonym of structor: Atanassov \& Dlussky (1992: 114) \\
\hline $\begin{array}{l}\text { Messor structor subsp. } \\
\text { turanicus }\end{array}$ & $\begin{array}{l}\text { Kuznetsov-Ugamsky, } \\
\text { 1927: } 91\end{array}$ & Uzbekistan & $\begin{array}{l}\text { junior synonym of rufitarsis ssp. darianus: Arnol'di (1977: } \\
\text { 1644) in key; of structor: Dlussky et al. (1990: 224) }\end{array}$ \\
\hline Messor structor var. subpolitus & $\begin{array}{l}\text { Kuznetsov-Ugamsky, } \\
\text { 1927: } 92\end{array}$ & Turkestan & junior synonym of clivorum: Tarbinsky (1976: 56) \\
\hline Messor structor var. aegaea & Menozzi, 1928: 126 & Turkey & $\begin{array}{l}\text { first available use of Messor barbarus st. structor var. aegaea } \\
\text { Emery, 1921: } 213\end{array}$ \\
\hline Messor structor subsp. novaki & Finzi, 1929: 92 & Yugoslavia & junior synonym of structor: Atanassov \& Dlussky (1992: 114) \\
\hline $\begin{array}{l}\text { Messor rufitarsis subsp. } \\
\text { darianus }\end{array}$ & Pisarski, 1967: 383 & Turkestan & $\begin{array}{l}\text { first available use of Messor structor st. rufitarsis var. dar- } \\
\text { ianus Santschi, 1926: 291; junior synonym of structor: } \\
\text { Kuznetsov-Ugamsky (1927: 92); synonymy of turanicus: } \\
\text { Pisarski (1967: 383) }\end{array}$ \\
\hline $\begin{array}{l}\text { Messor rufitarsis subsp. } \\
\text { tadzhikorum }\end{array}$ & Arnol'di, 1969: 79 & Tadzhikistan & $\begin{array}{l}\text { misspelled as rufitarsis tadzhicorum: Arnol'di (1977: 1644); } \\
\text { subspecies of structor: Bolton (1995: 257) }\end{array}$ \\
\hline $\begin{array}{l}\text { Messor rufitarsis subsp. } \\
\text { jakowlevi }\end{array}$ & Arnol'di, 1977: 1643 & Ukraine & $\begin{array}{l}\text { first available use of Messor barbarus subsp. capitatus var. } \\
\text { jakowlevi Ruzsky, 1905: 750; junior synonym of structor: } \\
\text { Dlussky et al. (1990: 224) }\end{array}$ \\
\hline Messor clivorum subsp. sevani & Arnol'di, 1977: 1644 & Caucasus & $\begin{array}{l}\text { first available use of Messor structor subsp. striaticeps var. } \\
\text { sevani Karawajew, 1926: 103; junior synonym of structor: } \\
\text { Arakelian (1994: 39) }\end{array}$ \\
\hline
\end{tabular}

species (Bourke \& Franks, 1995). Granted that species delimitation is subject to ongoing discussion (see Sites \& Marshall, 2003 for review) the species category is nonetheless of unquestioned operational value for systematics and phylogenetics (Avise \& Walker, 2000; Mallet, 2001). Hence in this paper we test a pair of alternative hypotheses whether the differing life histories of Central European Messor cf. structor harvester ants reflect (i) a single, bionomically versatile species; or (ii) two fully separated species.

Traditional insect classification is morphology-based; in particular morphometric analyses have proved powerful (Seifert, 2002). However, groups with small interspecific and high intraspecific variation are often poorly resolved by such methods alone (for review: Wiens, 1999; for ant examples: Lucas et al., 2002; Steiner et al., 2004, 2005, 2006a; Knaden et al., 2005). A strong, gradual size polymorphism within the worker caste of Central European Messor ants causes pronounced allometric distortions, making morphometric differentiation more complicated than in species with monomorphic workers (Csősz et al., unpubl.). In such cases molecular genetic analyses may provide complementary information. Morphologically most similar species may differ markedly in mitochondrial DNA (mtDNA), as shown for ants, among others, by Heinze et al. (2005), Knaden et al. (2005) and Steiner et al. (2004, 2005, 2006a).

In this paper the one-or-two-species problem in $M$. cf. structor is addressed by surveying its mtDNA diversity in Central Europe. In order to evaluate geographic, intraand interspecific variation samples from other European regions and other Messor species are included in the analysis.

\section{MATERIAL AND METHODS}

Individuals from 40 Messor colonies from ten European countries were studied (Table 2), including samples from German and Austrian populations, which reportedly differ bionomically (Fig. 1; Heller, 1971; Schlick-Steiner et al., 2005b). Voucher specimens were deposited in the Hungarian Natural History Museum in Budapest, the Babes-Bolyai University in Cluj-Napoca and the private collection of B.C. Schlick- 
TABLE 2. Localities and geographic coordinates, collectors, numbered haplotypes (HT) and phylogenetic lineages of the samples of $M$. cf. structor analysed. Abbreviations: AU - Austria; BU - Bulgaria; HR - Croatia; EZ - Czech Republic; FR - France; GM Germany; IT - Italy; RO - Romania; SI - Slovenia; SP - Spain. AMS - A.M. Stojanova; AS - A. Stradner; BM - B. Markó; BS B. Sipos; BSFS - B.C. Schlick-Steiner \& F.M. Steiner; CS - C. Stauffer; GB - G. Bračko; GH - G. Heller; HK - H. Konrad; JC J. Casevitz-Weulersse; KG - K. Gómez; KT - K. Ticha; NW - N. Weiß-Vogtmann; PSW - P.S. Ward; SC - S. Csősz; TL - T. Ljubomirov; XE - X. Espadaler.

\begin{tabular}{lllll}
\hline Species & Locality & Coordinates & Collector & HT \\
\hline Aphaenogaster iberica Emery, 1908 & SP: vic. Los Belones & $37^{\circ} 37^{\prime} \mathrm{N}, 00^{\circ} 48^{\prime} \mathrm{W}$ & AS, CS &
\end{tabular}

Messor bouvieri Bondroit, 1918

SP: Bellaterra

SP: Mallorca, Llucmajor

SP: Mallorca, Llucmajor

Messor capitatus (Latreille, 1798)

HR: Krk, Vrbnik

IT: Elba, Monte Orello

SI: Hrastovlje

SP: Oteo

Messor chamberlini Wheeler, 1915

Messor concolor Santschi, 1927

Messor lobognathus Andrews, 1916 Messor cf. structor (Latreille, 1798)

HR: vic. Biograd

IT: Elba, Monte Orello

US: Nevada, Washoe Co.

AU: Matzleinsdorf
US: California, Santa Barbara

BU: Maritsa valley, Klokotnitsa

BU: Maritsa valley, Klokotnitsa

AU: Obernalb

AU: Prellenkirchen

BU: Balcik

BU: Rhodope Mts., Daskalovo

BU: Strouma valley, vic. Zemen

BU: Strouma valley, vic. Zemen

BU: Strouma valley, vic. Zemen

EZ: Mohelno

EZ: Mohelno

FR: Les Auberasses, Vachères

FR: Rhône-Alpes

GM: Finthen

GM: Lorchhausen

GM: Mainz

HR: Krk, Malinska

IT: Verona

RO: Baile Herculane

RO: Dubova

RO: Macin Mts., Pricopanu

RO: Vama Veche

RO: Vama Veche

RO: Vama Veche

RO: Macin Mts., Pricopanu

RO: Caluseri

RO: Cluj Napoca

RO: Horia

SI: vic. Rakitovec

SI: Hrastovlje $41^{\circ} 30^{\prime} \mathrm{N}, 02^{\circ} 06^{\prime} \mathrm{E} \quad \mathrm{XE}$

$39^{\circ} 26^{\prime} \mathrm{N}, 02^{\circ} 45^{\prime} \mathrm{E} \quad \mathrm{KG}$

$39^{\circ} 26^{\prime} \mathrm{N}, 02^{\circ} 45^{\prime} \mathrm{E} \quad \mathrm{KG}$

$45^{\circ} 04^{\prime} \mathrm{N}, 14^{\circ} 40^{\prime} \mathrm{E} \quad \mathrm{HK}$

$42^{\circ} 42^{\prime} \mathrm{N}, 10^{\circ} 19^{\prime} \mathrm{E} \quad \mathrm{GH}$

$45^{\circ} 30^{\prime} \mathrm{N}, 13^{\circ} 53^{\prime} \mathrm{E}$ GB

$42^{\circ} 43^{\prime} \mathrm{N}, 02^{\circ} 22^{\prime} \mathrm{W} \quad \mathrm{XE}$

$34^{\circ} 00^{\prime} \mathrm{N}, 119^{\circ} 44^{\prime} \mathrm{W} \quad \mathrm{PSW}$

$41^{\circ} 58^{\prime} \mathrm{N}, 25^{\circ} 30^{\prime} \mathrm{E} \quad \mathrm{TL}$

$41^{\circ} 58^{\prime} \mathrm{N}, 25^{\circ} 35^{\prime} \mathrm{E} \quad \mathrm{TL}$

$43^{\circ} 56^{\prime} \mathrm{N}, 15^{\circ} 24^{\prime} \mathrm{E} \quad \mathrm{SC}$

$42^{\circ} 42^{\prime} \mathrm{N}, 10^{\circ} 19^{\prime} \mathrm{E} \quad \mathrm{GH}$

$41^{\circ} 31^{\prime} \mathrm{N}, 119^{\circ} 27^{\prime} \mathrm{W} \quad \mathrm{PSW}$

$48^{\circ} 12^{\prime} \mathrm{N}, 15^{\circ} 17^{\prime} \mathrm{E} \quad$ BSFS

$48^{\circ} 44^{\prime} \mathrm{N}, 15^{\circ} 55^{\prime} \mathrm{E} \quad$ BSFS

$48^{\circ} 05^{\prime} \mathrm{N}, 16^{\circ} 57^{\prime} \mathrm{E} \quad$ BSFS

$43^{\circ} 25^{\prime} \mathrm{N}, 28^{\circ} 10^{\prime} \mathrm{E}$

$41^{\circ} 46^{\prime} \mathrm{N}, 25^{\circ} 16^{\prime} \mathrm{E}$

$42^{\circ} 25^{\prime} \mathrm{N}, 22^{\circ} 44^{\prime} \mathrm{E}$

$42^{\circ} 28^{\prime} \mathrm{N}, 22^{\circ} 44^{\prime} \mathrm{E}$

$42^{\circ} 27^{\prime} \mathrm{N}, 22^{\circ} 44^{\prime} \mathrm{E}$

$49^{\circ} 07^{\prime} \mathrm{N}, 16^{\circ} 10^{\prime} \mathrm{E}$

$49^{\circ} 07^{\prime} \mathrm{N}, 16^{\circ} 10^{\prime} \mathrm{E}$

$43^{\circ} 55^{\prime} \mathrm{N}, 05^{\circ} 37^{\prime} \mathrm{E}$

$45^{\circ} 10^{\prime} \mathrm{N}, 05^{\circ} 20^{\prime} \mathrm{E}$

$49^{\circ} 59^{\prime} \mathrm{N}, 08^{\circ} 10^{\prime} \mathrm{E}$

$50^{\circ} 02^{\prime} \mathrm{N}, 07^{\circ} 46^{\prime} \mathrm{E}$

$50^{\circ} 00^{\prime} \mathrm{N}, 08^{\circ} 16^{\prime} \mathrm{E}$

$45^{\circ} 07^{\prime} \mathrm{N}, 1^{\circ} 31^{\prime} \mathrm{E}$

$45^{\circ} 27^{\prime} \mathrm{N}, 11^{\circ} 00^{\prime} \mathrm{E}$

$44^{\circ} 52^{\prime} \mathrm{N}, 22^{\circ} 24^{\prime} \mathrm{E}$

$44^{\circ} 37^{\prime} \mathrm{N}, 22^{\circ} 16^{\prime} \mathrm{E}$

$45^{\circ} 15^{\prime} \mathrm{N}, 28^{\circ} 09^{\prime} \mathrm{E}$

$43^{\circ} 45^{\prime} \mathrm{N}, 28^{\circ} 34^{\prime} \mathrm{E}$

$43^{\circ} 45^{\prime} \mathrm{N}, 28^{\circ} 34^{\prime} \mathrm{E}$

$43^{\circ} 45^{\prime} \mathrm{N}, 28^{\circ} 34^{\prime} \mathrm{E}$

$45^{\circ} 15^{\prime} \mathrm{N}, 28^{\circ} 09^{\prime} \mathrm{E}$

$46^{\circ} 36^{\prime} \mathrm{N}, 24^{\circ} 43^{\prime} \mathrm{E}$

$46^{\circ} 46^{\prime} \mathrm{N}, 23^{\circ} 36^{\prime} \mathrm{E}$

$45^{\circ} 01^{\prime} \mathrm{N}, 28^{\circ} 27^{\prime} \mathrm{E}$

$45^{\circ} 27^{\prime} \mathrm{N}, 13^{\circ} 58^{\prime} \mathrm{E}$

$45^{\circ} 30^{\prime} \mathrm{N}, 13^{\circ} 53^{\prime} \mathrm{E}$

BM 1 A

AMS 4 A

$\begin{array}{lll}\text { TL } & 3 & \text { A }\end{array}$

$\begin{array}{lll}\text { TL } & 3 & \mathrm{~A}\end{array}$

TL $11 \quad$ B

KT $11 \quad$ B

$\begin{array}{lll}\text { KT } & 11 \quad \text { B }\end{array}$

JC 1 A

NW 1 A

GH 1 A

GH 2 A

GH 1 A

HK 1 A

$\begin{array}{lll}\text { CS } & 1 & \text { A }\end{array}$

$\begin{array}{lll}\text { BM } & 8\end{array}$

BM $11 \quad$ B

BM $15 \quad$ B

BM 1 A

BM 1 A

BM 5 A

BM $14 \quad$ B

BM $12 \quad \mathrm{~B}$

BS $13 \quad$ B

BM $16 \quad \mathrm{~B}$

GB $\quad 7 \quad \mathrm{~B}$

GB $6 \quad$ B

Steiner \& F.M. Steiner. Workers were determined according to Agosti \& Collingwood (1987). The type of $M$. concolor Santschi, 1927 (Museo Civico di Storia Naturale, Genova) was inspected for comparison. Samples keying out as M. structor or $M$. muticus were subsumed under $M$. cf. structor, as differential diagnostic characters ( $M$. muticus: metasternal process wider; scape, relative to head width, shorter) were found to vary considerably within single colonies, and not correlated with the geographic origin of the samples. In total 29 colonies of $M$. cf. structor, four of $M$. capitatus (Latreille, 1798), four of M. concolor and three of $M$. bouvieri Bondroit, 1918 were analysed. $M$. chamberlini Wheeler, 1915, M. lobognathus Andrews, 1916, both from North America (det. P.S. Ward), and Aphaenogaster iberica Emery, 1908 from Spain (det. X. Espadaler), were selected as the outgroup.

DNA of single individuals was extracted, using the Genelute Extraction kit (Sigma, St. Louis, USA), but applying the standard phenol-chloroform-isoamyl-alcohol protocol (Sambrook et 
al., 1989) for some individuals. PCR was performed in two different ways: 50 / $25 \mu 1$ reaction volume; 4 / $3 \mu$ l template DNA; $1 \times$ reaction buffer; $0.2 / 0.4 \mathrm{mM}$ dNTPs; $0.2 / 1.0 \mu \mathrm{M}$ forward and reverse primers; 2 / $3.5 \mathrm{U}$ Taq DNA polymerase (Sigma / Promega, Madison, USA) and $\mathrm{ddH}_{2} \mathrm{O}$. In the $25 \mu 1$ reactions 3 $\mathrm{mM} \mathrm{MgCl}{ }_{2}$ was added. Alternative PCR conditions were $1 \mathrm{~min}$ at $94^{\circ} \mathrm{C}, 31$ cycles of $1 \mathrm{~min}$ at $94^{\circ} \mathrm{C}, 30 \mathrm{~s}$ at varying annealing temperatures $\left(47-55^{\circ} \mathrm{C}\right)$ and $2 \mathrm{~min}$ at $72^{\circ} \mathrm{C}$, final step $2 \mathrm{~min}$ at $72^{\circ} \mathrm{C} ; 10 \mathrm{~min}$ at $94^{\circ} \mathrm{C}, 35$ cycles of $1 \mathrm{~min}$ at $94^{\circ} \mathrm{C}, 30 \mathrm{~s}$ at $50^{\circ} \mathrm{C}$ and $2 \mathrm{~min}$ at $72^{\circ} \mathrm{C}$ and a final step of $10 \mathrm{~min}$ at $72^{\circ} \mathrm{C}$. Primers used for amplification of a 1584 bp long cytochrome oxidase subunit I (COI) gene segment were LCO1490 (Folmer et al., 1994) and Pat (Simon et al., 1994). For some samples we used the self-designed primers "Simon", 5'TTGTCTTTACCTGTTCTTGC-3' and "Garfunkel", 5'TCCTATAGCTCATCAAAGAGAAGG-3' for sequencing.

PCR products were purified using the QIAquick PCR purification kit (Qiagen, Hilden, Germany) and then either directly sequenced in both directions using the Big Dye termination reaction chemistry (Applied Biosystems, Foster City, USA) or sequenced after cloning (pGEM-T vector, Promega and DH5a E. coli cells, plasmid DNA was extracted with the QIAprep Miniprep-kit (Qiagen), sequenced with the M13 universal primer), and analysed with an ABI 377, or, alternatively, with an ABI Prism 310 automatic sequencer (Applied Biosystems).

$1255 \mathrm{bp}$ were used for phylogenetic analyses. Nucleotide sequence alignment was achieved with Clustal $\mathrm{X}$ using the default settings (Thompson et al., 1997). To compare the relationships among sequences broken down to haplotypes, distance (Neighbour Joining algorithm, NJ, based on Tamura-Nei distance) and character (maximum parsimony, MP; Bayesian Markov Chain Monte Carlo BMCMC) analyses were performed using PAUP* (test version 4.0b3a; Swofford, 1998) and MrBayes v3.1 (Ronquist \& Huelsenbeck, 2003). For MP analysis all characters were assigned equal weights. MP trees were generated with heuristic search using the tree bisectionreconnection branch swapping with 10 random taxon addition sequence replicates and the Multree option in effect. The maximum number of trees in memory was set to 10,000 . Bootstrapping was applied for NJ (1000 replicates) and MP trees (100 replicates). Prior to BMCMC analysis the GTR $+\mathrm{I}+\mathrm{G}$ model (Tavaré, 1986; Yang, 1993) was chosen using Modeltest 3.06 (Posada \& Crandall, 1998), which uses hierarchical likelihood ratio tests (Huelsenbeck \& Rannala, 1997) to determine how well competing substitution models fit the data. In BMCMC analysis $1,000,000$ generations with a sample frequency set to 100 were run twice. As after 750,000 generations stationarity was achieved (average standard deviation of split frequencies stable at 0.004), the last 2,500 trees of each run were used to compute a majority rule consensus tree assigning posterior probabilities of tree topology.

\section{RESULTS}

The 1255 bp sequences of the COI gene of all samples were deposited in GenBank under accession numbers DQ074323-DQ074365. No gaps arose in alignment. All phylogenetic analyses (Fig. 1) revealed that $A$. iberica was closer to the ingroup (M. cf. structor, M. bouvieri, $M$. concolor and $M$. capitatus) than $M$. chamberlini and $M$. lobognathus. M. capitatus, M. concolor and M. bouvieri had maximum node support in all trees (bootstrap values of NJ and MP, posterior probability values of BMCMC). The order of divergence of $M$. capitatus, $M$. concolor and $M$. bouvieri was differently resolved by $\mathrm{NJ} / \mathrm{MP}$ and
BMCMC analyses. Minimum interspecific sequence divergence between these species varied from 8.5 to $11.3 \%$. Maximum intraspecific variation within M. bouvieri (3 haplotypes), M. concolor (4) and M. capitatus (3) ranged from 0.2 to $0.6 \%$.

Within the 29 samples determined as Messor cf. structor, mutations at 166 sites (17 mutations at the first, two at the second, and 147 at the third codon position) resulted in 16 haplotypes with a maximum sequence divergence of $9.3 \%$ (Fig. 1). All phylogenetic trees revealed the monophyly of $M$. cf. structor and samples determined as $M$. cf. structor always clustered into the same two major lineages, arbitrarily termed A and B. Number of samples in lineage A was 14 in B 15 . Node support for the two lineages were maximum in all trees. Maximum sequence divergence within the lineages was $2.4 \%$ in lineage $\mathrm{A}$ and $5.1 \%$ in lineage $\mathrm{B}$. Minimum sequence divergence between lineages was $7.1 \%$. Moreover, in all trees the two major lineages were substructured and the sublineages were supported by very high node support values (Fig. 1). Lineage A contained two sublineages, comprising haplotypes HT1-HT2 and HT3-HT5, with a minimum divergence of $2.3 \%$ between them. Lineage B contained four sublineages, HT6-HT7, HT8-HT11, HT12-HT13 and HT14-HT16, with minimum sequence divergences between the sublineages ranging from 3.6 to $5.1 \%$. To test for a possible saturation effect on the phylogenetic signal at the third codon position, a NJ search based only on the first and second positions of the COI data was conducted (tree not shown). The $M$. cf. structor lineages A and B, as well as all sublineages, were confirmed by high node support values.

The map of where the samples of $M$. cf. structor (Fig. 1) were collected suggests a geographic separation of DNA lineages with partial overlaps. Lineage A has a larger distribution area; from France and Germany in the west to Bulgaria and Romania in the east. Lineage B is found from Bulgaria to Romania and Austria with its westernmost record from Slovenia. In the Dinaric and Balkan region the distribution areas overlap.

\section{DISCUSSION}

The mtDNA trees indicate that the genus Messor, as currently understood, may be polyphyletic since Aphaenogaster iberica occurs closer to the Palearctic Messor than to the Nearctic outgroup species Messor lobognathus and M. chamberlini. This agrees with morphological findings (male genitalia: P.S. Ward, pers. comm.; presence / absence of strong propodeal spines in the worker caste: Csösz, unpubl.) and contributes to the dispute on the generic classification of Nearctic "Messor" species (reviewed by Brown, 1974 and Bolton, 1982).

Considerable genetic variation was found in the mitochondrial $C O I$ gene among samples determined as $M$. cf. structor. The two major lineages A and B are very far apart. The minimum divergence of $7.1 \%$ between the lineages is in the order of magnitude of the minimum interspecific divergences between $M$. bouvieri, M. concolor and $M$. capitatus (8.5-11.3\%; Fig. 1) and that 


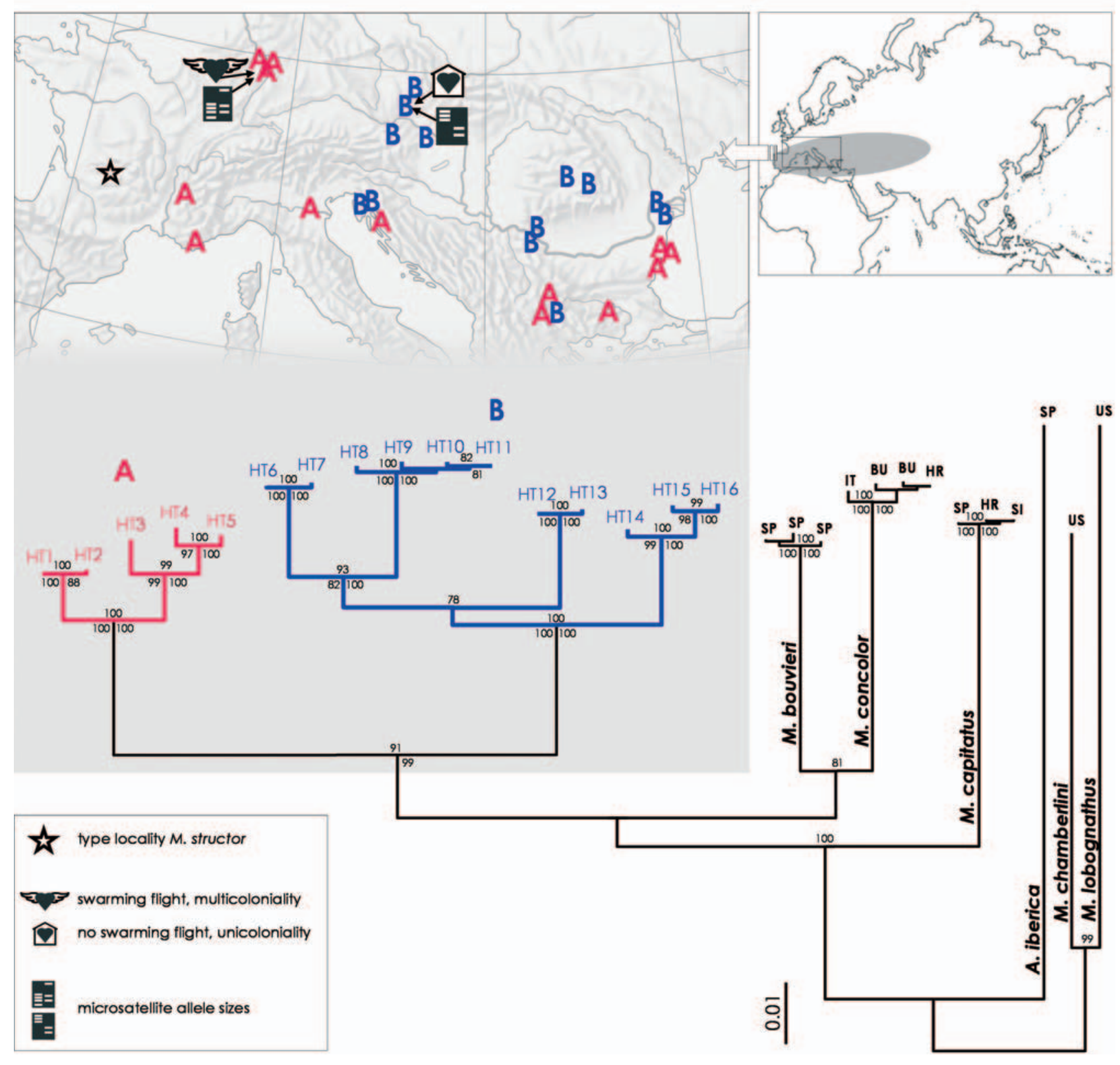

Fig. 1. Phylogeny of Messor cf. structor. Small map: Distribution of Messor structor (according to Czechowski et al., 2002). Large map: Type locality of M. structor (star symbol) and populations of M. cf. structor sampled (letters A and B, referring to major lineages in the tree). Phylogenetic tree: Neighbour Joining tree of $1255 \mathrm{bp}$ of the $C O I$ gene, Tamura-Nei algorithm; haplotypes of $M$. cf. structor (16 HT numbered as in Table 2, grey shading) and of M. bouvieri, M. concolor and M. capitatus, with M. chamberlini, M. lobognathus and A. iberica as outgroup (country of origin indicated). The scale bar denotes 0.01 substitutions / site. Bootstrap values $>75 \%$ are given above nodes, bootstrap values of the congruent unweighted MP branches are to the left of nodes, posterior probability values $>75$ of the congruent BMCMC branches to the right of nodes.

between congeners of Cardiocondyla, Cataglyphis, Lasius, Myrmica and Tetramorium ants (Savolainen \& Vepsäläinen, 2003; Steiner et al., 2004, 2005, 2006a, b; Knaden et al., 2005; Heinze et al., 2005). Thus, the mtDNA data are compatible with the two-specieshypothesis.

For a profound evaluation of genetic variation, however, nuclear markers should be analysed in addition to mtDNA (Beltrán et al., 2002; Lin \& Danforth, 2004), and molecular data should be substantiated by other approaches such as morphology, karyology, semiochemistry and ecology (Wetterer et al., 1998; Ross, 2001; Lucas et al., 2002; Ward \& Brady, 2003; Janda et al., 2004; Seifert \& Goropashnaya 2004; Steiner et al., 2004; Knaden et al., 2005; Maeder et al., 2005; Schlick-Steiner et al., 2005a; Ward \& Downie, 2005). This should also rule out hybridization with a hitherto not included Messor species and introgression of its haplotypes resulting in the observed mtDNA pattern (cf. Ross \& Shoemaker, 2005). 
Preliminary microsatellite data of German lineage A and Austrian lineage B populations (Arthofer et al., 2005) suggest a complete separation of allele size at one microsatellite locus (MS2D) and a private allele of the German populations at another (MS2C; Fig. 1). Current morphological analyses (Csősz et al., unpubl.) additionally corroborate that these populations belong to different species.

Overall, the evidence presented here leads us to reject the hypothesis that there is only one species of Messor harvester ants in Central Europe. The alternative hypothesis of two species, corresponding to lineages A and B, clearly is more plausible. Messor cf. structor thus encompasses a cryptic species in Central Europe. Only by in-depth analyses will it be possible to evaluate whether the distinct substructuring of $\mathrm{A}$ and $\mathrm{B}$ in the mtDNA trees is due to the existence of even more than two species. The high minimum divergence values between sublineages of A $(2.3 \%)$ and B (3.6-5.1\%) are compatible with this scenario.

Under these circumstances the assignment of species names to mtDNA lineages is futile. It is not even clear which lineage should bear the name Messor structor (Latreille, 1798), since the original description is vague and the type material lost (J. Casevitz-Weulersse, Museum of Natural History, Paris, pers. comm.). Biogeographic considerations tentatively point to lineage A because it is the only lineage presently known from the terra typica in France (Fig. 1). For the remaining lineages any of 19 taxon names currently classified as subspecies or junior synonyms of Messor structor could apply (Table $1)$.

From a phylogeographic point of view the distributions of lineages $\mathrm{A}$ and $\mathrm{B}$ are remarkable. The disjunction in Central Europe (Fig. 1) suggests different routes of dispersal, probably from a common Pleistocene refugium: a bypass of the Alps in the west by the ancestors of the German populations, as hypothesized for the butterfly Polyommatus coridon (Schmitt et al., 2002) and for certain dragonflies (Sternberg, 1998), and a bypass in the east by the ancestors of the Austrian and Czech populations.

ACKNOWLEDGEMENTS. We gratefully thank the Austrian Science Foundation (FWF P16794-B06), the Romanian National University Research Council (CNCSIS 45/379) and the Hungarian National Research and Development Programme (3B023-04) for funding; the persons listed in Table 2 for providing samples; W. Arthofer, D. Avtzis, O. Popescu and A. Stradner for laboratory assistance; A. Buschinger, J. CasevitzWeulersse, X. Espadaler, B. Seifert and P.S. Ward for valuable information and helpful discussions; two anonymous referees for constructive criticism; and J. Plant for linguistic improvements.

\section{REFERENCES}

Agosti D. \& Collingwood C.A. 1987: A provisional list of the Balkan ants (Hym., Formicidae) and a key to the worker caste. II. Key to the worker caste, including the European species without the Iberian. Mitt. Schweiz. Entomol. Ges. 60: 261-293.
Arakelian G.R. 1994: Fauna of the Republic of Armenia. Hymenoptera. Ants (Formicidae). Gitutyun Publishing House NAN RA, Yerevan, 153 pp. [in Russian].

ARNOL'DI K.V. 1969: New species and races of ants of the genus Messor (Hymenoptera, Formicidae). Zool. Zh. 49: 72-88 [in Russian].

ARNOL'DI K.V. 1977: Survey of harvester ants of the genus Messor (Hymenoptera, Formicidae) of the fauna of the USSR. Zool. Zh. 56: 1637-1648 [in Russian].

Arthofer W., Schlick-Steiner B.C., Steiner F.M., Konrad H., Espadaler X. \& Stauffer C. 2005: Microsatellite loci for the study of habitat fragmentation in the harvester ant Messor structor. Conserv. Genet. 6: 859-861.

Atanassov N. \& Dlussky G.M. 1992: Hymenoptera, Formicidae. Fauna Bulg. 22: 1-310 [in Bulgarian].

Avise J.C. \& WaLker D. 2000: Abandon all species concepts? A response. Conserv. Genet. 1: 77-80.

Beltrán M., Jiggins C.D., Bull V., Linares M., Mallet J., McMillan W.O. \& Bermingham E. 2002: Phylogenetic discordance at the species boundary: comparative gene genealogies among rapidly radiating Heliconius butterflies. Mol. Biol. Evol. 19: 2176-2190.

BERNARD F. 1955 [1954]: Fourmis moissonneuses nouvelles ou peu connues des montagnes d'Algérie et révision des Messor du groupe structor (Latr.). Bull. Soc. Hist. Nat. Afr. Nord 45: 354-365.

Bernard F. 1967 [1968]: Faune de l'Europe et du Bassin Méditerranéen. 3. Les fourmis (Hymenoptera Formicidae) d'Europe occidentale et septentrionale. Masson, Paris, 411 pp.

BEZDEČKa P. 1996: The ants of Slovakia (Hymenoptera: Formicidae). Entomofauna Carpath. 8: 108-114 [in Slovakian, English abstr.].

Bolton B. 1982: Afrotropical species of the myrmicine ant genera Cardiocondyla, Leptothorax, Melissotarsus, Messor and Cataulacus (Formicidae). Bul. Br. Mus. Nat. Hist. (Entomol.) 45: 307-370.

Bolton B. 1995: A New General Catalogue of the Ants of the World. The Belknap Press of Harvard University Press, Cambridge, MA, 504 pp.

BourKe A.F.G. \& FranKs N.R. 1995: Social Evolution in Ants. Princeton University Press, Princeton, NJ, 529 pp.

Brown W.L. 1974: Novomessor manni a synonym of Aphaenogaster ensifera (Hymenoptera: Formicidae). Entomol. News 85: $45-53$.

Cagniant H. \& Espadaler X. 1997: Le genre Messor au Maroc (Hymenoptera: Formicidae). Ann. Soc. Entomol. Fr. 33: 419-434.

Crawley W.C. 1920: Ants from Mesopotamia and north-west Persia. Entomol. Rec. J. Var. 32: 162-166.

Crozier R.H. \& PAmilo P. 1996: Evolution of Social Insect Colonies. Oxford University Press, NY, $306 \mathrm{pp}$.

Czechowski W., Radchenko A. \& Czechowska W. 2002: The Ants (Hymenoptera, Formicidae) of Poland. Studio 1, Warszawa, 200 pp.

Dlussky G.M., Soyunov O.S. \& Zabelin S.I. 1990: The Ants of Turkmenistan. Ashkhabad, 273 pp. [in Russian].

EMERY C. 1897: Anhang. Verzeichniss der auf der zweiten Riese nach Kleinasien (1897) gesammelten Ameisen, mit einer Neubeschreibung. p. 239 in Escherich, K. Zur Kenntnis der Myrmecophilen Kleinasiens. I. Coleoptera. Wien. Entomol. Ztg. 16: 229-239.

EMERY C. 1898: Beiträge zur Kenntniss der palaearktischen Ameisen. Öfvers. Fin. Vetensk. Soc. Förh. 40: 124-151. 
Emery C. 1908: Beiträge zur Monographie der Formiciden des paläarktischen Faunengebietes. (Hym.). Teil III. Dtsch. Entomol. Z. 1908: 437-465.

EMERY C. 1921: Formiche raccolte a Budrum (Anatolia) da Raffaele Varriale, Cap. Medico nella R. Marina. Ann. Mus. Civ. Stor. Nat. Genova 9: 208-218.

Fabricius J.C. 1804: Systema Piezatorum. Carolum Reichard, Brunsviga, $439 \mathrm{pp}$.

FINZI B. 1929: Le forme italiane del genere Messor (Formicidae - Myrmicinae). Boll. Soc. Entomol. Ital. 61: 75-94.

Folmer O., Black M., Hoeh W., Lutz R. \& Vrijenhoek R. 1994: DNA primers for amplification of mitochondrial cytochrome c oxidase subunit I from diverse metazoan invertebrates. Mol. Mar. Biol. Biotechnol. 3: 294-299.

Gallé L., Csösz S., Tartally A. \& Kovács É. 1998: A checklist of Hungarian ants. Folia Entomol. Hung. 59: 213-220.

Heinze J., Trindl A., Seifert B. \& Yamauchi K. 2005: Evolution of male morphology in the ant genus Cardiocondyla. Mol. Phylogen. Evol. 37: 278-288.

Heller G. 1971: Beitrag zur Kenntnis der im Gebiet von Schwabenheim/Selz (Rheinhessen) vorkommenden Ameisenarten. Master's thesis. Johannes Gutenberg-Universität Mainz, Mainz, 45 pp.

Huelsenbeck J.P. \& Rannala B. 1997: Phylogenetic methods come of age: testing hypotheses in an evolutionary context. Science 276: 227-232.

Janda M., Folková D. \& ZrZavý J. 2004: Phylogeny of Lasius ants based on mitochondrial DNA and morphology, and the evolution of social parasitism in the Lasiini (Hymenoptera: Formicidae). Mol. Phylogen. Evol. 33: 595-614.

Karawajew V. 1926: Beiträge zur Ameisenfauna des Kaukasus, nebst einigen Bemerkungen über andere palaearktische Formen. (Schluss). Konowia 5: 187-199.

Knaden M., Tinaut A., Cerda X., Wehner S. \& Wehner R. 2005: Phylogeny of three parapatric species of desert ants, Cataglyphis bicolor, C. viatica and C. savignyi: a comparison of mitochondrial DNA, nuclear DNA, and morphological data. Zoology 108: 169-177.

KutTer H. 1977: Hymenoptera: Formicidae. Schweizerische Entomologische Gesellschaft, Zürich, 298 pp.

KUZNETSOV-UGAMSKY N.N. 1927: Vorläufige Uebersicht über die mittelasiatischen Formen der Gattung Messor (Hym., Form.). Folia Myrmecol. Termit. 1: 89-94.

LAtreIlle P.A. 1798: Essai sur l'histoire des fourmis de la France. F. Bourdeaux, Brive, $50 \mathrm{pp}$.

Lin C.-P. \& Danforth B.N. 2004: How do insect nuclear and mitochondrial gene substitution patterns differ? Insights from Bayesian analyses of combined datasets. Mol. Phylogen. Evol. 30: 686-702.

Lucas C., Fresneau D., Kolmer K., Heinze J., Delabie J.H.C. \& PHO D.B. 2002: A multidisciplinary approach to discriminating different taxa in the species complex Pachycondyla villosa (Formicidae). Biol. J. Linn. Soc. 75: 249-259.

Maeder A., Freitag A. \& Cherix D. 2005: Species- and nestmate brood discrimination in the sibling wood ant species Formica paralugubris and Formica lugubris. Ann. Zool. Fennici 42: 201-212.

Mallet J. 2001: Species, concepts of. In Levin S. (ed.): Encyclopedia of Biodiversity. Vol. 5. Academic Press, San Diego, pp. 427-440.

MARKó B. \& Csősz S. 2002: Die europäischen Ameisenarten (Hymenoptera: Formicidae) des Hermannstädter (Sibiu, Rumänien) Naturkundemuseums I.: Unterfamilien Ponerinae, Myrmicinae und Dolichoderinae. Ann. Hist. Nat. Mus. Nat. Hung. 94: 109-121.
MAYR G. 1855: Formicina austriaca. Beschreibung der bisher im österreichischen Kaiserstaate aufgefundenen Ameisen nebst Hinzufügung jener in Deutschland, in der Schweiz und in Italien vorkommenden Ameisen. Verh. Zool. Bot. Ver. Wien 5: 273-478.

Menozzi C. 1928: Note sulla mirmecofauna paleartica. Boll. Lab. Zool. Gen. Agrar. R. Sc. Super. Agric. 21: 126-129.

Neumeyer R. \& Seifert B. 2005: Kommentierte Liste der frei lebenden Ameisen (Hymenoptera: Formicidae) in der Schweiz. Mitt. Schweiz. Entomol. Ges. 78: 1-17.

Nylander W. 1849 [1848]: Additamentum alterum adnotationum in monographiam formicarum borealium. Acta Soc. Sci. Fenn. 3: 25-48.

PISARSKI B. 1967: Fourmis (Hymenoptera: Formicidae) d'Afghanistan récoltées par M. Dr. K. Lindberg. Ann. Zool. (Warsaw) 24: 375-425.

Posada D. \& Crandall K.A. 1998: Modeltest: testing the model of DNA substitutions. Bioinformatics 14: 817-818.

Ronquist F. \& Huelsenbeck J.P. 2003: MrBayes 3: Bayesian phylogenetic inference under mixed models. Bioinformatics 19: $1572-1574$.

Ross K.G. 2001: Molecular ecology of social behaviour: analyses of breeding systems and genetic structure. Mol. Ecol. 10: $265-284$.

Ross K.G. \& Shoemaker D.D. 2005: Species delimitation in native South American fire ants. Mol. Ecol. 14: 3419-3438.

RuzsKY M. 1905: Formicariae Imperii Rossii. [The ants of Russia.] Tr. Obshch. Estestvoispyt. Imp. Kazan. Univ. 38: 1-800 [in Russian].

Sambrook J., Fritsch E.F., Maniatis T. 1989: Molecular Cloning: A Laboratory Manual. 2nd ed. Cold Spring Harbor Laboratory Press, New York.

SANTSCHI F. 1917: Races et variétés nouvelles du Messor barbarus L. Bull. Soc. Hist. Nat. Afr. Nord 8: 89-94.

SANTSCHI F. 1923: Messor et autres fourmis paléarctiques. Rev. Suisse Zool. 30: 317-336.

SAnTschi F. 1926: Travaux scientifiques de l'Armée d'Orient (1916-1918). Fourmis. Bull. Mus. Natl. Hist. Nat. 5: 286-293.

SANTSChI F. 1927: Revision des Messor du groupe instabilis Sm. (Hymenopt.). Bol. R. Soc. Esp. Hist. Nat. 27: 225-250.

Savolainen R. \& VepsäläInen V. 2003: Sympatric speciation through intraspecific social parasitism. Proc. Natl. Acad. Sci. USA 100: 7169-7174.

SCHILLING P.S. 1839: Bemerkungen über die in Schlesien und der Grafschaft Glatz vorgefundenen Arten der Ameisen. Übers. Arb. Veränd. Schles. Ges. Vaterl. Kult. 1838: 51-56.

Schlick-Steiner B.C., Steiner F.M., Sanetra M., Heller G., Stauffer C., Christian E. \& Seifert B. 2005a: Queen size dimorphism in the ant Tetramorium moravicum (Hymenoptera, Formicidae): Morphometric, molecular genetic and experimental evidence. Insect. Soc. 52: 186-193.

Schlick-Steiner B.C., Steiner F.M., Stauffer C. \& Buschinger A. 2005b: Life history traits of a European Messor harvester ant. Insect. Soc. 52: 360-365.

Schmitt T., Giessl A. \& Seitz A. 2002: Postglacial colonisation of western Central Europe by Polyommatus coridon (Poda 1761) (Lepidoptera: Lycaenidae): evidence from population genetics. Heredity 88: 26-34.

SEIFERT B. 1996: Ameisen: Beobachten, bestimmen. Naturbuch Verlag, Augsburg, 352 pp.

SeIfert B. 2001: Formicidae. In Dathe H.H., Taeger A. \& Blank S.M. (eds): Entomofauna Germanica. Band 4. Verzeichnis der Hautflügler Deutschlands. Entomol. Nachr. Ber., Dresden, Beiheft 7: 125-129, 172. 
SeIfert B. 2002: How to distinguish most similar insect species - improving the steremicroscopic and mathematical evaluation of external characters by example of ants. J. Appl. Entomol. 126: 1-9.

Seifert B. \& Goropashnaya A.V. 2004: Ideal phenotypes and mismatching haplotypes - errors of mtDNA treeing in ants (Hymenoptera: Formicidae) detected by standardized morphometry. Organ. Diver. Evol. 4: 295-305.

Simon C., Frati F., Beckenbach A., Crespi B., Liu H. \& Flook P. 1994: Evolution, weighting, and phylogenetic utility of mitochondrial gene sequences and a compilation of conserved polymerase chain reaction primers. Ann. Entomol. Soc. Am. 87: 651-701.

Sites J.W. \& Marshall J.C. 2003: Delimiting species: a renaissance issue in systematic biology. Trends Ecol. Evol. 18: $462-470$.

Steiner F.M., SchöDl S. \& Schlick-Steiner B.C. 2003: Liste der Ameisen Österreichs (Hymenoptera: Formicidae), Stand Oktober 2002. Beitr. Entomofaun. 3: 17-26.

Steiner F.M., Schlick-Steiner B.C., SchÖdl S., Espadaler X., Seifert B., Christian E. \& Stauffer C. 2004: Phylogeny and bionomics of Lasius austriacus (Hymenoptera, Formicidae). Insect. Soc. 51: 24-29.

Steiner F.M., Schlick-Steiner B.C., Sanetra M., Ljubomirov T., Antonova V., Christian E. \& Stauffer C. 2005: Towards DNA-aided biogeography: an example from Tetramorium ants (Hymenoptera, Formicidae). Ann. Zool. Fenn. 42: 23-35.

Steiner F.M., Schlick-Steiner B.C., Trager J.C., Moder K., Sanetra M., Christian E. \& Stauffer C. 2006a: Tetramorium tsushimae, a new invasive ant in North America. Biol. Invas. 8: $117-123$.

Steiner F.M., Schlick-Steiner B.C., Konrad H., Moder K., Christian E., Seifert B., Crozier R.H., Stauffer C. \& BuschINGER A. 2006b: No sympatric speciation here: Multiple data sources show that the ant Myrmica microrubra is not a separate species but an alternate reproductive morph of Myrmica rubra. J. Evol. Biol. (in press).

SternBERG K. 1998: The postglacial colonization of Central Europe by dragonflies, with special reference to southwestern Germany (Insecta, Odonata). J. Biogeog. 25: 319-337.
Stiтz H. 1939: Hautflügler oder Hymenoptera I: Ameisen oder Formicidae. Gustav Fischer, Jena, 428 pp.

Swofford D.L. 1998: PAUP*: Phylogenetic Analysis Using Parsimony (*and Other Methods). Version 4.0b3. Sinauer, Sunderland, MA.

TARBINSKY Y.S. 1976: [The Ants of Kirghizia (Hymenoptera, Formicidae)]. Ilim, Frunze, 217 pp. [in Russian].

TAVARÉ S. 1986. Some probabilistic and statistical problems in the analysis of DNA sequences. Lect. Math. Life. Sci. 17: $57-86$.

Thompson J.D., Gibson T.J., Plewniak F., Jeanmougin F. \& HigGINS D.G. 1997: The Clustal-X windows interface: Flexible strategies for multiple sequence alignment aided by quality analysis tools. Nucl. Acids Res. 25: 4876-4882.

Toнmé G. \& Toнmé H. 1981: Les fourmis du genre Messor en Syrie. Position systématique. Description de quelques ailés et de formes nouvelles. Répartition géographique. Ecol. Mediterr. 7: 139-153.

Ward P.S. \& Brady S.G. 2003: Phylogeny and biogeography of the ant subfamily Myrmeciinae (Hymenoptera: Formicidae). Invertebr. Syst. 17: 361-386.

WARD P.S. \& Downie D.A. 2005: The ant subfamily Pseudomyrmecinae (Hymenoptera: Formicidae): phylogeny and evolution of big-eyed arboreal ants. Syst. Entomol. 30: 310-335.

WeRner P. \& BEZDEČKA P. 2001: Checklist of ants of the Czech Republic. Sbor. Př́r. Klubu U. Hradišti 6: 174-183 [in Czech, English abstr.].

Wetterer J.K., Schultz T.R. \& Meier R. 1998: Phylogeny of fungus-growing ants (Tribe Attini) based on mtDNA sequence and morphology. Mol. Phylogenet. Evol. 9: 42-47.

WIENS J.J. 1999: Polymorphism in systematics and comparative biology. Annu. Rev. Ecol. Syst. 30: 327-362.

WILSON E.O. 1971: The Insect Societies. Harvard University Press, Cambridge, MA, 548 pp.

YANG Z. 1993: Maximum likelihood estimation of phylogeny from DNA sequences when substitution rates differ over sites. Mol. Evol. Biol. 10: 1396-1401.

Received June 2, 2005; revised and accepted November 21, 2005 